\title{
Fiscal Contingencies due to Changes in the Method of Calculating the PIS and COFINS Levies in Brazil
}

\author{
Antonio Lopo Martinez \\ Fucape Business School \\ Brazil \\ Kassila Spinassé Sonegheti \\ Fucape Business School \\ Brazil
}

Received: August 25, 2015

Accepted: Nov. 4, 2015

Published: January 1, 2016

doi:10.5296/jmr.v8i1.8196

URL: http://dx.doi.org/10.5296/jmr.v8i1.8196

\begin{abstract}
This paper studies the effects of change in the method of calculating the PIS and COFINS in the disclosure of tax contingencies. The tax contingencies in general, including contingencies related tax contributions, must be evidenced in financial statement notes, in accordance with established accounting criteria for this purpose. In this context, this study analyzes the disclosure level of Brazilian companies reporting in the financial statement notes to the tax contingent assets and liabilities, especially with regard to non-cumulative PIS and COFINS, and what its features. To assess the level of disclosure of contingencies it applied a Probit model in which it tried to identify the determinants of disclosure level. The results suggest that the majority of the firms analyzed, although they have fiscal contingencies related to PIS and COFINS, do not explain the nature of the respective accounting figures in financial statement notes, so they are not being transparent to investors in this respect.
\end{abstract}

Keywords: Fiscal contingencies, provisions, financial statement notes, disclosure 


\section{Introduction}

Brazil has one of the world's highest overall tax burdens, a fact that has a considerable effect on firms' bottom-line results. Besides the cost of the taxes themselves, there is also a substantial cost for compliance with the welter of accessory obligations (record-keeping and reporting requirements). This is particularly true of taxes involving offsetting debits and credits, as is the case of the two contributions that are the focus of this article. According to Junqueira (2010), firms face the challenge of structuring their tax planning and systems of controls to minimize the overall tax obligation and thus to maintain competitiveness while also reducing the risk of erroneous or illegal decisions and the consequent contingent liabilities created.

Failure to comply with tax legislation and regulations, or divergent interpretation from that adopted by the tax authorities, can cause large contingencies, depending on the outcome of uncertain future events (e.g., success or failure in administrative and/or judicial proceedings). These contingencies can arise from more aggressive and efficient oversight by the tax administration or because of abusive tax planning. According to Hanlon \& Heitzman (2010), recent academic works have expanded thinking on the theme, incorporating the effects of corporate governance to tax planning. The delicate problem facing firms is to lower their tax liability as much as possible without overstepping the rules and creating a worse situation due to penalties and litigation costs.

The alteration of the criterion for calculating PIS, established by Law 10,637/2002, and of COFINS, instituted by Law 10,833/2003, led firms to seek tax-planning alternatives to reduce the burden of these levies. For Fernandes et al. (2010), there are indications that the overall burden of these two levies increased with the new calculation method (although this depends on the activities of each company, thus creating winners and losers), but in general the non-cumulative method is less distortionary to the economy than the cumulative system.

Previous studies have indicated that besides the overall increase in the tax burden (Oliveira, 2011), the new laws created a mismatch between the fiscal and accounting concepts for application of the new rules. This opened space for questions by the tax authorities of the practices adopted by firms, resulting in an increase in infraction citations and deficiency assessments, including due to disallowance of credits. These are often not based on intentionally illicit behavior, but rather on honestly divergent interpretation of the complex rules between firms and the tax authorities.

Considering that the change in the method for calculating PIS and COFINS caused an increase in the burden from these two levies for most firms, the aim of this study is the answer the following question: What are the determinants of the level of disclosure of contingencies related to PIS and COFINS after the change in the calculation criterion? To do this, we try to identify the factors that lead companies to report their contingent assets and liabilities regarding these two contributions in their financial statement notes and to identify if the information disclosed is comprehensible and relevant to users of accounting information. 
The specific objectives are: a) to verify whether the change in the criterion for calculating PIS and COFINS caused an increase in infraction citations/deficiency assessments; b) to identify if firms are clearly or obscurely representing their contingent assets and liabilities in notes to the financial statements; and c) to analyze whether the disclosure or not of fiscal contingencies is related to the level of corporate governance.

The justification for this study is its innovation in examining the motives that lead companies not to disclose certain required information in their financial reports. Despite the importance of fiscal contingencies to companies and investors, we assume that this information overall is not being fully disclosed by firms in explanatory notes, despite being obligatory according to IAS 37 - Provisions, Contingent Liabilities and Contingent Assets.

The above rule only exemplifies that amounts at issue in judicial proceedings should be disclosed. Nevertheless, the discussions in the administrative sphere can also have a major impact on the bottom-line results, because many firms do not continue the discussion in the courts of the final administrative decision in tax disputes. Additionally, tax administration may not do so (the tax authorities can only sue to collect debts definitively constituted at the administrative level, not seek to overturn a ruling in favor of the taxpayer).

\section{Theoretical Framework}

\subsection{Fiscal Contingencies}

As pointed out by Hanlon \& Heitzman (2010), taxes can play an important role in decisions in the corporate world, including policies on investments, capital structure and form of organization. Disclosure of the reasons for these decisions is important to enable investors to reach informed decisions. Bushman \& Smith (2001), cited by Lima (2009), affirm that accounting information affects economic performance through three channels: in the first, accounting information helps managers and investors to identify good and bad growth opportunities; the second involves revelation of corporate governance policies; and the third reduces adverse selection and liquidity risk.

According to Reagle (2006), it is hard to find empirical evidence of fiscal management by companies. Phillips \& Sancing (1998) state that taxpayers can be defined as agents that use specialized fiscal knowledge to resolve uncertainties about the applicable rules, allowing them to reach informed decisions to minimize their expected tax costs. Graham et al. (2011) found that besides being valuable to managers and investors, tax information is valuable to the tax authorities, to improve their oversight and enforcement actions. Indeed, they are the main users of tax information.

Based on Elliott \& Jacobson (1994) and Healy \& Palepu (2001), Macagnan (2009) stated, "The signaling of a firm's differences in relation to possible future gains is a positive motivation for managers to disclose information. The threat of litigation is another motivation for managers to increase or decrease the level of disclosure, due to the possibility of lawsuits by investors for inadequate disclosure, untimely disclosure or nondisclosure."

The disclosure of accounting information in notes, besides demonstrating transparency, helps 
investors and external users to interpret otherwise obscure information. In Brazil, Pronouncement 25 from the Accounting Pronouncements Council (CPC 25) suggests the basic criteria for recognizing and measuring provisions and contingent assets and liabilities, so that the information will be sufficient to enable users to understand the nature and value of the provisions.

The concept of contingency can be defined as a possible obligation or a right resulting from a past event whose existence will be confirmed or not by uncertain future events that are not under the firm's control. Nevertheless, the word contingency can have various nuances of interpretation, according to the area of knowledge to which it applies. According to Bruseke (2007), in common usage the concept of contingency is often taken as a synonym for "chance" or something "unforeseen".

In accounting, a contingency can be either favorable or unfavorable. It reflects the financial effects existing on the date of the accounting statements that depend on uncertain future events. CPC 25 requires that events that can be estimated as probable, possible or remote be to be treated as contingencies. The debts with probable estimation of materializing should be provisioned as liabilities, because they will likely cause a decrease in net worth, while those classified as only possible or remote only need to be mentioned in explanatory notes.

Schadewitz \& Blevins (1998) concluded that more research is necessary to gain a better understanding of how the market in general uses information based on provisioning. Currently the legislation and regulations assume that the same types of disclosure apply to various types of business.

Accounting is objectively a system of information and evaluation intended to provide its users with statements and analyses of an economic, financial and physical nature regarding the organization to which the accounting information pertains. Gonçalves \& Ott $(2002$, p. 3), cited by Oliveira \& Pontes (2004), refer to the duty of disclosure as going beyond just publication of the accounting numbers, also covering the obligation to provide relevant information to interpret the raw numbers, through the management report discussing the financial statements and explanatory notes, as well as through periodic press releases and meetings with analysts, among others.

CPC 25 and IAS 37 define the criteria for provisions, contingent liabilities and contingent assets. Some criteria must be obeyed for an event to be defined as a provision and contingent liability, and to a certain extent the two concepts overlap, because all provisions are in fact contingent since they are uncertain regarding their period, value and likelihood of materialization, just as are contingent liabilities. The difference is that provisions are obligations with probable chances of materializing, with consequent reduction of net worth, while contingent liabilities are obligations of possible or even remote chances of materializing, due to law, regulation, contractual demand or informal requirement. On the other side of the ledger, contingent assets are not to be recognized, but should be disclosed in explanatory notes when the future economic benefits are deemed probable. Therefore, in general, the form of recognizing or disclosing contingencies in the financial statements depends on the likelihood of their materialization, and there should be sufficient information 
in notes to enable users to understand the reasons for the relative probability of occurrence.

As noted by Schiff et al. (2012), companies in general are more conservative in disclosing contingent fiscal assets, i.e., possible benefits or refunds due to the outcome of administrative or judicial litigation, than they are in disclosing possible tax debts.

Just as for other contingencies, tax contingencies can be defined as the uncertain effects on either the asset or liability side that depend on the outcome of litigation, with remote, possible or probable chances of materializing, for better or for worse. In this study, we investigate tax contingencies in general and the characteristics of the firms that disclose this information, with focus on the contingencies involving non-cumulative PIS and COFINS, exactly because the calculation of these two levies is complex and subject to legitimate differences of interpretation between firms and the tax administration. The study by Haddad (2004) found that the tax burden in Brazil increased considerably in 2003 in relation to 2002, representing an increase of $9 \%$ in revenue from the two contributions.

Not only did the new system increase the average tax burden on companies, it also substantially increased the compliance burden, because of the complexity of applying the new rules, causing a good deal of disagreement between companies and the Federal Revenue Secretariat (RFB, the Brazilian IRS). The increased tax burden, however, did not necessarily mean that the contingencies increased, at least not immediately, because the increased effective rate of these two contributions caused many companies to engage in more aggressive tax planning, but over the longer run, this tends to cause more litigation due to deficiency assessments, thus increasing contingencies.

\subsection{Non-cumulative PIS and COFINS}

The idea behind non-cumulative taxes is neutrality in relation to previous steps in the production or distribution chain and in relation to the economic capacity of the taxpayer. Until the issuance of the definitive legal framework for the non-cumulative system of these social contributions, the reimbursement of PIS and COFINS charged previously on raw materials, intermediate products and packaging materials to be applied for the manufacture of goods for export was done by granting a presumed IPI ${ }^{1}$ credit, calculated based on the provisions of Law 9,363/1996.

The publication of Provisional Measures ${ }^{2}$ 66/2002 and 135/2003, along with the enactment of Laws $10,833 / 03$ and $10,637 / 2002$, operationalized the non-cumulative system for the two contributions, bringing a new scenario. The form of computing them is through a debit based on the gross revenue of the company, irrespective of the nomenclature or accounting classification, excluding the revenues legally exempt from taxation. Article 3 of Laws $10,637 / 2002$ (PIS) and 10,833/2003 (COFINS) allow taxpayers to deduct credits related to the acquisition of materials that will be used in the production of finished products for sale.

\footnotetext{
${ }^{1}$ IPI is the Tax on Manufactured Products, a federal levy on the value added during the fabrication process, with offsetting credits from the tax paid by suppliers in previous steps (on raw materials, intermediate goods and packaging materials used to produce finished products).

${ }^{2}$ Provisional measures (medidas provisórias) are presidential decrees that take effect immediately with status of ordinary law, but are then subject to congressional amendment or rejection, on an urgent basis in the legislative agenda.
} 
Note that the referred laws do not limit the PIS and COFINS paid previously on products used for the manufacture as deductible under the non-cumulative regime, but rather all items used in production. Previously, Normative Ruling 65/1979 from the Tax System Coordination Office (CST) defined inputs for purposes of IPI credits as those products that integrate the final product (raw materials, intermediate products and packaging materials), and any other objects that undergo alterations, such as wear and tear or loss of physical or chemical properties directly due to the manufacture of the finished product, provided they can be classified as fixed assets according to generally accepted accounting principles. However, the concept of production is broader than that of manufacture. Production covers all the operations of the company, while manufacture only involves the transformation of materials to obtain a new product. So besides the deductions related to materials, the legislation brought the option of obtaining credits on services used in the production process.

According to Carraza (2002), the principle of non-cumulative taxation is not a legal creation, but instead a constitutional one. If it resulted from a law, then the rules could be changed or the system even eliminated at any time by Congress. However, as a constitutional definition, an ordinary law cannot interfere in its meaning, content or scope. Therefore, since laws cannot deal specifically with each productive activity, there can be divergences between companies and the tax authorities, generating deficiency assessments and infraction citations related to the two contributions.

In this respect, Oliveira (2011) concluded that the mismatch between the accounting and fiscal concepts of inputs has a negative effect on the amount of credits that can be appropriated and thus the bottom-line results of companies, to the tune of $1.57 \%$ lower profits.

Calijuri (2009) found that companies are taking a broader view of tax planning, by which immediate minimization of taxes is seen as not necessarily maximizing profits over the long run, because overly aggressive tax planning can generate other costs as a side effect, not taken into account in a more restricted analysis.

The changes brought by the new criterion for calculation requires careful control over the credits that can be used to abate the PIS and COFINS debts, to avoid deficiency assessments. The amounts of credits that exceed the debits, according to the non-cumulative criterion, can be used to offset other federal taxes and contributions. However, according to Federal Revenue Normative Instruction 600/2005, any debts so offset are deemed definitively confessed by the taxpayer. More important, Brazilian Internal Revenue has five years to contest any credits used to offset PIS and COFINS debts or other taxes. After this period, any tax claims are time-barred by peremption (decadência), and then the tax administration has a further five years to sue to collect any unpaid taxes, according to the time-bar by prescription (prescrição). The doubt about whether or not netting of taxes will wind up being allowed (either tacitly by formal acceptance or implicitly by failure to act before peremption operates) tends to create contingencies, which should be properly reported as assets or liabilities in notes to the financial statements. 


\subsection{Previous studies of PIS and COFINS}

As mentioned, previous studies have shown indications that the overall tax burden increased with the change in the criterion for computing PIS and COFINS, with a negative impact on the bottom line of the firms studied (Fernandes et al., 2010). For Pimenta (1972), the taxes levied in non-cumulative form, although charged on all phases of the process of production and/or circulation of goods, should only reflect the value added to the product at each step. Madeira (2009) found that although in theory the non-cumulative PIS and COFINS regime serves as an instrument to optimize collection, level the competitive playing field and adjust taxation to the capacity to pay, this has not happened in practice.

With respect to interpretation, Canado (2011) concluded that the rules on PIS and COFINS are abstract, impairing determination of the exact tax liability, and the continuing discussions in the doctrine from legal scholars and divergences in the jurisprudence from the courts leaves a climate of contention between taxpayers and the tax authorities, and hence causes the need to report contingencies while waiting for final resolution of disputes. Finally, Xavier (2011) observed that the liberty of lawmakers to choose how to put the non-cumulative system into practice is restricted to choice of the method, not the extension of its effects, so that lawmakers have the duty to guarantee that the choice of the method does not create ill-conceived effects.

\section{Methodology.}

\subsection{Scope of the study}

Initially to detect the increase in fiscal contingencies related to non-cumulative PIS and COFINS, we obtained data from the Federal Revenue Secretariat (RFB) on the result of audits involving these taxes, to learn the amounts involved in deficiency assessments and infraction citations (fines for failure of record keeping/reporting obligations, etc.) as well as the disallowance of credits, covering the period from 2002 to 2010, to enable comparison of the period just before the start of the non-cumulative system and since then. These numbers are only available in aggregate form due to the rules on fiscal secrecy established by Law $12,527 / 2011$, making it impossible to identify the specific amounts at the company level.

To verify whether companies are disclosing the contingencies related to deficiency assessments and infraction citations related to PIS and COFINS as assets or liabilities, we analyzed the notes to the financial statements of the firms composing the IBrX-100 index in the first four months of 2013, referring to the annual reports for 2009 to 2011, to identify the information made available. The choice of this period was due to the mentioned five-year limitation period for the tax authorities to issue assessments. Therefore, we assumed that after the change in the criterion for calculating PIS and COFINS, the tax authorities only started in earnest the process of reviewing the tax filings involving non-cumulative PIS/COFINS in 2008, so that explanatory notes would only start to be expected in significant numbers in 2009.

The IBrX-100 is composed of the 100 companies with the greatest trading on the $\mathrm{BM} \& \mathrm{FBovespa}$ in terms of number of trades and financial volume. We excluded financial 
institutions because they are subject to the cumulative regime for PIS and COFINS. According to Madeira (2009), it is reasonable to establish that PIS and COFINS are cumulative for some companies and non-cumulative for others, depending on the activities, the tax regime, size and form of corporate organization. After this exclusion, there were 234 observations. We obtained additional information (size, corporate governance, and sector) about those companies from the Economática database, for the same period.

\subsection{Content analysis of the explanatory notes}

The notes should complement the financial statements to provide information necessary for a proper evaluation of the evolution of the assets and liabilities of the company, as relevant for comprehension of the numbers presented in the balance sheet and various statements (CPC 26).

Kelsen (2011) pointed out that when the legal system connects a determined fact as a presupposition for a certain consequence, it needs to determine the authority entrusted with judging the case and the procedure to be followed. In the case of taxes, the entities empowered to judge cases are the RFB (through regional judgment offices) at the first administrative instance and the Administrative Tax Appeal Council (CARF) at the second level, after which it is up to the courts to decide finally, if the taxpayer decides to pursue that route, either actively by filing a suit against the tax administration to preclude assessment of a tax or passively by waiting for a tax collection suit. In the judicial sphere, there are three levels of jurisdiction for federal taxes: the first instance federal courts, the regional federal courts of appeal and the Superior Tribunal of Justice for non-constitutional matters and the Federal Supreme Court for constitutional questions. A case can take several years to reach final resolution after all appeals are exhausted.

Considering that companies should disclose in explanatory notes the information on ongoing cases in the administrative or judicial sphere in which they are parties, and based on the assumption that companies that are more transparent provide more information in this respect, we analyzed the explanatory notes on fiscal contingencies involving potential assets and liabilities to gauge the level of disclosure according to the firms' characteristics. With respect to transparency, Cohen et al. (2011) concluded that the market attributes a higher value to firms that offer stronger guarantees, but also found evidence that firms tend to manage earnings so as to meet targets or analysts' projections.

We divided the information disclosed about fiscal contingencies into taxes in general and non-cumulative PIS and COFINS in particular. Analysis of the 234 observations for the period from 2009 to 2011 showed that $65 \%$ of the firms analyzed disclosed notes on non-provisioned tax contingencies in general, while $21 \%$ did so regarding PIS and COFINS. Furthermore, $82 \%$ established provisions in their balance sheets only for contingencies with risk of loss rated as probable resulting from judicial decisions pending appeal for final resolution. The companies with higher level of governance did not show better results, because of the firms composing the Novo Mercado trading segment of the BM\&FBovespa (which requires enhanced governance mechanisms), only 55\% disclosed fiscal contingencies in notes, although some did report they had no type of contingency to report, such as OGX 
Petróleo e Gás Participações S/A for 2011:

“On December 31, 2011 and December 31, 2010, the Company was not a defendant in any suits with expectation of loss considered to be probable (chance of loss greater than $50 \%$ ), so no provisions were established for contingencies. On the referred dates, the Company also was not a defendant in relevant disputes in which losses were considered possible."

The companies that disclosed tax contingencies with possible chance of loss maintained this information for all the years. Due to the size of the companies analyzed, we expected most of them to have some contingency of a fiscal nature.

The objective of this study is to identify what factors prompt firms to report contingent tax assets and liabilities in their notes and identify if that disclosure tendency is linked to their characteristics. To identify this relationship, we used as the dependent variable (y) the level of disclosure of fiscal contingencies, on a scale of 0,1 and 2, where:

0: represents firms that do not disclose any tax contingencies in general;

1: represents firms that disclose tax contingencies in general but do not disclose any regarding non-cumulative PIS and COFINS;

2: represents firms that disclose tax contingencies in general and also disclose contingencies regarding non-cumulative PIS and COFINS.

Table 1 shows the descriptive statistics of the classification of the level of disclosure of tax contingencies. As can be seen, there are 89 observations of firms with score 0 (38.03\%), 96 with score $1(41.03 \%)$ and 49 with score $2(20.94 \%)$ over the three-year study period.

Table 1. Descriptive Statistics of the Level of Disclosure of Tax Contingencies

\begin{tabular}{c|c|c|c}
\hline Level of disclosure of tax contingencies & $\begin{array}{c}\text { Level of } \\
\text { disclosure of tax } \\
\text { contingencies }\end{array}$ & $\begin{array}{c}\text { Level of } \\
\text { disclosure of } \\
\text { tax } \\
\text { contingencies }\end{array}$ & $\begin{array}{c}\text { Level of } \\
\text { disclosure of } \\
\text { tax } \\
\text { contingencies }\end{array}$ \\
\hline 0 & 0 & 0 & 0 \\
1 & 1 & 1 & 1 \\
\hline 2 & 2 & 2 & 2 \\
\hline Total & Total & Total & Total \\
\hline
\end{tabular}

Analyzing each year alone shows that in $2009,48 \%$ of the firms disclosed tax contingencies without provisions, while in 2010 this percentage increased to $58 \%$ and to $62 \%$ in 2011 . These results suggest that over the period studied, the companies improved their disclosure of information, although it is not possible to identify with certainty a reason for this pattern. It might be that the convergence to international accounting standards contributed to this, but this analysis is beyond our scope here. There was a tendency for some firms to consistently disclose contingencies and for others not to do so consistently.

\subsection{Multivariate analysis - probit model}

To analyze the characteristics of the firms that disclosed non-provisioned contingencies, we 


\section{Macrothink}

used the ordered probit model, which allows analyzing the dependent variable when it is discrete and qualitative, to rank the possible results of the regression:

Disclosure Level - Tax Contingencies $=\beta_{0}+\beta_{1} N P_{j}+\beta T A_{j}+\beta_{3} P R_{j}+\beta_{4}$ Lnrev $_{j}+\beta$ GOVERNANCE $_{j}+$ $\beta_{6} D 1_{j}+\beta_{7} \mathcal{D}_{j}+\beta_{8} D 3_{j}+\beta_{9} D 4_{j}+\beta_{10} D 5_{j}+\beta_{11} D 6_{j}+\beta_{12} D 7_{j}+\beta_{13} D 8_{j}+\beta_{14} D 9_{j}+\beta_{15} D 10_{j}+$

$\beta_{16} D 11_{j}+\beta_{17} D 12_{j}+\varepsilon$

Where:

- TAX_CONT_DISC: variable that defines the level of disclosure of tax contingencies, on the scale from 0 to 2 described above;

- NP: net profit in year t;

- TA: total assets in year t;

- PR: value of provisions in year $t$;

- LnRev: natural log of revenue in year $t$;

- Gov: dummy control variable, with the value of 1 for firms with enhanced governance and 0 otherwise;

- $\quad$ D1 to D12: dummies for firms in the sectors analyzed.

The independent variables are:

Net Profit (NP): corresponds to the net profit or loss of the company in the year. We expect the inclusion of this variable to enable identifying whether there was any change in the level of disclosure according to whether the firm made a profit or loss.

Total Assets (TA): corresponds to the total assets in each year, to indicate the size of the firm.

Governance (Gov): corresponds to the level of transparency. According to Desai \& Dharmapala, (2007), the tax system can attenuate or enhance the level of corporate governance.

Provisions (PR): corresponds to the value of the provisions reported in notes. We assume that firms with larger provisions are more conservative in disclosing that information in the notes.

Revenues (LnRev): corresponds to the natural logarithm of the yearly revenues of the firms in the sample.

Sector (d1 to d12): correspond to the sectors analyzed. In each case, the variable has value of 1 for firms in the respective sector and 0 for other firms. The sectors are identified in the chart below. 


\begin{tabular}{|c|c|}
\hline Variable & Sector \\
\hline D1 & Foods and Beverages \\
\hline D2 & Commerce \\
\hline D3 & Construction \\
\hline D4 & Electricity \\
\hline D5 & Mining \\
\hline D6 & Others \\
\hline D7 & Pulp and Paper \\
\hline D8 & Oil and Gas \\
\hline D9 & Steel and Metallurgy \\
\hline D10 & Telecommunications \\
\hline D11 & Transportation \\
\hline D12 & Vehicles and Parts \\
\hline
\end{tabular}

We used the Stata ${ }^{\circledR}$ program to analyze the 78 firms over the period from 2009 to 2011 , for 234 observations, organized in a panel. According to Hsiao (2003), cited in Moreira et al. (2010), analysis of panel data in comparison with cross-sectional or time-series models presents advantages such as controlling for some statistical problems (e.g., heterogeneity of data for different individuals), increasing the degrees of freedom and reducing the collinearity of the explanatory variables.

\section{Analysis of the Results.}

Based on the assumption that larger firms are audited more frequently and account for a larger portion of the revenue from these contributions, we identified the contingent assets and liabilities disclosed in notes. Companies that are more transparent tend to more accurately inform the market of their current and future financial position.

While the amounts involved in deficiency assessments and infraction citations (which often come at the same time, the first for failure to report revenue and pay the tax and the second for infraction of record-keeping obligations or late payment/reporting) rose sharply, albeit with a good deal of volatility, as of 2004, reaching $R \$ 8$ billion in 2010 , the amounts of credits taken and later disallowed in audits only started to rise as of 2008 (note that there were no credits to disallow before the establishment of the non-cumulative regime, for PIS starting in 2003 and Cofins in 2004). Finally, the number of firms audited did not increase substantially in the period.

The data gathered from the explanatory notes for 2009 to 2011 suggest some characteristics of the firms and the way they disclosed information over the years. As can be seen in Table 2, more companies disclosed more information about tax contingencies in 2011 than in 2009, with the average for the three years being $68.56 \%$ of the companies analyzed. Contingencies related to PIS and COFINS in general were reported by an average of $30.57 \%$ of the companies, while only $11.35 \%$ of them disclosed information specifically about non-cumulative PIS and COFINS. Finally, the average of companies that disclosed information about administrative litigation involving tax matters was $47.60 \%$, with a slightly 
rising trend.

Table 2. Information by Year

\begin{tabular}{c|c|c|c|c|c}
\hline Year & $\begin{array}{c}\text { Number of } \\
\text { observations }\end{array}$ & $\begin{array}{c}\text { Did the } \\
\text { company } \\
\text { disclose any } \\
\text { information in }\end{array}$ & $\begin{array}{c}\text { Did the company } \\
\text { disclose any } \\
\text { information in tax } \\
\text { contingencies } \\
\text { tax }\end{array}$ & $\begin{array}{c}\text { Did the company } \\
\text { disclose any } \\
\text { information in tax } \\
\text { contingencies } \\
\text { related to } \\
\text { contingencies? }\end{array}$ & $\begin{array}{c}\text { COFINS? } \\
\text { Did the company } \\
\text { disclose any } \\
\text { information } \\
\text { regarding }\end{array}$ \\
\hline 2009 & 78 & $64.00 \%$ & $30.67 \%$ & $10.67 \%$ & $46.67 \%$ \\
2011 & 78 & $68.83 \%$ & $31.17 \%$ & $11.69 \%$ & $46.75 \%$ \\
\hline Mean & $\mathbf{2 3 4}$ & $\mathbf{6 8 . 5 6 \%}$ & $\mathbf{3 0 . 5 7 \%}$ & $\mathbf{1 1 . 3 5 \%}$ & $49.35 \%$ \\
\hline
\end{tabular}

Source: Authors.

With respect to the level of corporate governance, the results were similar, as shown in Table 3. The explanatory notes of firms with an enhanced level of governance on average offered less information, because they provisioned smaller amounts and the value of non-provisioned contingencies was lower.

The same relation holds for information regarding administrative litigation. The firms with enhanced governance disclosed less than other firms. Of the sample of 234 observations, 210 were represented by companies with some level of higher governance, but only $26.83 \%$ of the observations involved disclosure of contingencies related to PIS and COFINS.

Table 3. Companies Classified by Level of Governance

\begin{tabular}{|c|c|c|c|c|c|}
\hline $\begin{array}{c}\text { Enhanced } \\
\text { governance } \\
\text { level }\end{array}$ & $\begin{array}{c}\text { Number of } \\
\text { observations }\end{array}$ & $\begin{array}{c}\text { Did the } \\
\text { company } \\
\text { disclose any } \\
\text { information in } \\
\text { tax } \\
\text { contingencies? }\end{array}$ & $\begin{array}{c}\text { Did the } \\
\text { company } \\
\text { disclose any } \\
\text { information in } \\
\text { tax } \\
\text { contingencies } \\
\text { related to PIS } \\
\text { and COFINS? }\end{array}$ & $\begin{array}{l}\text { Did the company } \\
\text { disclose any } \\
\text { information in tax } \\
\text { contingencies } \\
\text { related to } \\
\text { non-cumulative } \\
\text { PIS and } \\
\text { COFINS? }\end{array}$ & $\begin{array}{l}\text { Did the company } \\
\text { disclose any } \\
\text { information } \\
\text { regarding } \\
\text { administrative } \\
\text { tax disputes? }\end{array}$ \\
\hline NO & 24 & $95.83 \%$ & $62.50 \%$ & $25.00 \%$ & $75.00 \%$ \\
\hline YES & 210 & $65.37 \%$ & $26.83 \%$ & $9.76 \%$ & $44.39 \%$ \\
\hline Mean & 234 & $68.56 \%$ & $30.57 \%$ & $11.35 \%$ & $47.60 \%$ \\
\hline
\end{tabular}

Source: Authors.

Analysis of the companies by sector, as shown in Table 4, indicated variations in disclosure behavior. The sector with the most informative companies regarding PIS and COFINS contingencies was foods and beverages. 
Table 4. Companies By Sector

\begin{tabular}{|c|c|c|c|c|c|}
\hline Sectors & $\begin{array}{c}\text { Number of } \\
\text { observations }\end{array}$ & $\begin{array}{c}\text { Did the } \\
\text { company } \\
\text { disclose any } \\
\text { information in } \\
\text { tax } \\
\text { contingencies? }\end{array}$ & $\begin{array}{c}\text { Did the } \\
\text { company } \\
\text { disclose any } \\
\text { information in } \\
\text { tax } \\
\text { contingencies } \\
\text { related to PIS } \\
\text { and COFINS? }\end{array}$ & $\begin{array}{c}\text { Did the } \\
\text { company } \\
\text { disclose any } \\
\text { information in } \\
\text { tax } \\
\text { contingencies } \\
\text { related to } \\
\text { non-cumulative } \\
\text { PIS and } \\
\text { COFINS? }\end{array}$ & $\begin{array}{c}\text { Did the } \\
\text { company } \\
\text { disclose any } \\
\text { information } \\
\text { regarding } \\
\text { administrative } \\
\text { tax disputes? }\end{array}$ \\
\hline Foods and Bev. & 15 & $87 \%$ & $80 \%$ & $67 \%$ & $60 \%$ \\
\hline Commerce & 18 & $83 \%$ & $50 \%$ & $0 \%$ & $67 \%$ \\
\hline Construction & 27 & $44 \%$ & $22 \%$ & $0 \%$ & $22 \%$ \\
\hline Electricity & 36 & $82 \%$ & $48 \%$ & $0 \%$ & $45 \%$ \\
\hline Mining & 9 & $44 \%$ & $0 \%$ & $0 \%$ & $33 \%$ \\
\hline Others & 48 & $51 \%$ & $17 \%$ & $6 \%$ & $38 \%$ \\
\hline Pulp and Paper & 9 & $44 \%$ & $0 \%$ & $0 \%$ & $33 \%$ \\
\hline Oil and Gas & 12 & $27 \%$ & $27 \%$ & $27 \%$ & $27 \%$ \\
\hline Chemicals & 3 & $100 \%$ & $67 \%$ & $0 \%$ & $67 \%$ \\
\hline Steel and Metallurg. & 12 & $100 \%$ & $25 \%$ & $8 \%$ & $100 \%$ \\
\hline Software and Data & 3 & $100 \%$ & $0 \%$ & $0 \%$ & $100 \%$ \\
\hline Telecom. & 9 & $100 \%$ & $56 \%$ & $33 \%$ & $100 \%$ \\
\hline Textiles & 3 & $100 \%$ & $0 \%$ & $0 \%$ & $0 \%$ \\
\hline Transportation & 15 & $100 \%$ & $0 \%$ & $0 \%$ & $13 \%$ \\
\hline Vehicles and Parts & 15 & $67 \%$ & $40 \%$ & $40 \%$ & $80 \%$ \\
\hline Mean & 234 & $69 \%$ & $31 \%$ & $11 \%$ & $48 \%$ \\
\hline
\end{tabular}

Source: Authors.

In general, the companies disclosed very little information regarding contingencies related to non-cumulative PIS and COFINS. The disclosure rate in this respect was zero among firms in the commerce, construction, electricity, mining, pulp and paper, chemicals, software, textiles and transportation sectors, although firms in all sectors disclosed tax contingencies in general. Among all the companies in the sample, $48 \%$ offered information in notes on administrative tax proceedings, while $69 \%$ of the firms disclosed tax contingencies in general.

Table 5 shows the results of the probit model for the 234 observations to discern the factors associated with disclosure of contingent assets and liabilities and the characteristics of the firms.

Net profit had a positive influence on the level of disclosure, $1.00 \mathrm{e}-07$ higher in relation to the average disclosure level on a scale from 0 to 2 . Therefore, profit had a positive impact on the firms' disclosure level (firms with higher profits tended to be more informative in the period studied). 
Again there were variations according to the sector of activity, with the construction, mining, others and pulp and paper sectors being statistically distinct, although with negative coefficients, indicating a high and negative correlation with the level of disclosure of fiscal contingencies. Companies in the food and beverage sector had a disclosure level of 0.0894565 higher than the average on the 0 to 2 scale. The significance of the model according to the $\mathrm{LR}$ statistic was $\mathrm{LR}=100.07$ (Prob. $\mathrm{LR}=0.000$ ) while the pseudo-R2 obtained in the test was 0.2110 .

When evaluating the response of the independent variables to the dependent variable, "total assets" (TA) varied 2.3 times when the disclosure level varied by one unit while the "revenue" variable (LnRev) varied 15.07 times when the disclosure level varied by one unit. The other variables had lower responses to each variation of the dependent variable.

Tax contingencies in general had a low disclosure level among the firms studied, although significant in the medium term. The administrative disputes involving the firms can turn into large liabilities over the medium term and can have a large negative effect on future cash flow. Although the data from the Federal Revenue Secretariat revealed that the value of contingencies related to the change in the calculation of PIS and COFINS increased considerably over the years analyzed, the firms studied disclosed very little information about contingencies related to these levies.

Table 5. Probit Model - Dependent Variable - Disclosure Level - Tax Contingencies

\begin{tabular}{l|c|c|c|c|c|c|c}
\hline \multicolumn{1}{c|}{ Variable } & $\mathbf{d y} / \mathbf{d x}$ & $\mathbf{S t d} \mathbf{D e v}$ & $\mathbf{z}$ & $\mathbf{P}>\mathbf{z}$ & \multicolumn{2}{|c}{$[\mathbf{9 5 \% .}$ Conf.Inver] } & $\mathbf{X}$ \\
\hline LL & $1.00 \mathrm{e}-07$ & $4.11 \mathrm{e}-0 \mathrm{~B}$ & 2.44 & 0.015 & $1.99 \mathrm{e}-0 \mathrm{~B}$ & $1 . \mathrm{B} 1 \mathrm{e}-07$ & $1.4 \mathrm{e}+06$ \\
TA & $-8,93 \mathrm{E}-09$ & $3.40 \mathrm{e}-09$ & -2.63 & 0.009 & $-1.56 \mathrm{e}-0 \mathrm{~B}$ & $-2.27 \mathrm{e}-09$ & $2.3 \mathrm{e}+07$ \\
Prov & $-4.65 \mathrm{e}-07$ & $3.16 \mathrm{e}-07$ & -1.47 & 0.141 & $-1.0 \mathrm{Be}-06$ & $1.54 \mathrm{e}-07$ & 136134 \\
LnRev & .4272719 & .092407 & 4.62 & 0.000 & .2461576 & $.60 \mathrm{~B} 3 \mathrm{~B} 62$ & 150.706 \\
Governance & $-.063 \mathrm{BB} 12$ & $.2 \mathrm{BB} 95 \mathrm{~B} 5$ & -0.22 & $0 . \mathrm{B} 25$ & -.6302295 & .5024671 &. $\mathrm{~B} 92377$ \\
D1 - Food and Bev & $.0 \mathrm{~B} 94565$ & $.4 \mathrm{~B} 7 \mathrm{~B} 52$ & $0.1 \mathrm{~B}$ & $0 . \mathrm{B} 55$ &.$- \mathrm{B} 667159$ & 1.045 .629 & .067265 \\
D2 - Commerce & -.3367995 & $.42106 \mathrm{~B} 6$ & $-0 . \mathrm{B} 0$ & 0.424 & -1.162 .079 & $.4 \mathrm{BB} 479 \mathrm{~B}$ & $.0 \mathrm{~B} 0717$ \\
D3 - Construction & -1.542 .359 & .4050567 & $-3 . \mathrm{B} 1$ & 0.000 & -2.336 .255 & $-.74 \mathrm{~B} 4621$ & .121076 \\
D4 - Eletricity & $-.6110 \mathrm{~B} 25$ & .3750495 & -1.63 & 0.103 & -1.346 .166 & .124001 & .161435 \\
D5 - Mining & -1.435 .902 & .697342 & -2.06 & 0.039 & $-2 . \mathrm{B} 02.66 \mathrm{~B}$ & -.0691371 & .026906 \\
D6 - Others & $-.726 \mathrm{~B} 53 \mathrm{~B}$ & .3571157 & -2.04 & 0.042 & $-1.426 .7 \mathrm{BB}$ & $-.026919 \mathrm{~B}$ & .242152 \\
D7 - Pulp and Paper & -1.391 .066 & .5177771 & -2.69 & 0.007 & $-2.405 \mathrm{~B} 9$ & -.3762411 & .040359 \\
D8 - Oil and Gas & $-.032 \mathrm{BB} 61$ & .7906452 & -0.04 & 0.967 & $-1.5 \mathrm{~B} 2.522$ & 151.675 & $.035 \mathrm{~B} 74$ \\
D9 - Stell and Metallurg & $-.34210 \mathrm{~B} 2$ & $.50513 \mathrm{~B} 9$ & $-0.6 \mathrm{~B}$ & $0.49 \mathrm{~B}$ & -1.332 .162 & .6479459 & $.053 \mathrm{~B} 12$ \\
D10 - Telecom. & .1304734 & $.5352 \mathrm{BBB}$ & 0.24 & $0 . \mathrm{B} 07$ & $-.91 \mathrm{~B} 6734$ & 117.962 & .040359 \\
D11 - Transportatiom & $-.69 \mathrm{~B} 1222$ & .4293731 & -1.63 & 0.104 & $-1.539 .67 \mathrm{~B}$ & .1434336 & .067265 \\
D12 - Vehicles and Parts & (omitted) & & & & & & \\
\hline
\end{tabular}

\section{Conclusion}

The findings of the present study show that contingencies related to non-cumulative PIS and COFINS increased considerably during the period studied, especially as of 2006, and that 
despite this increase, few companies disclose contingent assets and liabilities related to these contributions in the notes to their financial statements. We cannot affirm which companies had contingencies related to PIS and COFINS, because this would have required identification through specific questionnaires. However, the companies analyzed in the sample are on the list of firms that attract special attention by the Federal Revenue Secretariat, so it is reasonable to assume that all the firms had tax contingencies in general.

This assumption was borne out, because despite the low disclosure rate of PIS and COFINS contingencies, most of the companies reported tax contingencies in general, showing a concern for transparency, although firms in some sectors did not disclose any contingencies. In addition, although the majority of the companies reported contingent assets and/or liabilities, some data were not properly revised, which impaired the analysis. In general, the level of governance did not exert an influence on the quality of the explanatory notes.

The disclosure of tax contingencies in notes was positively influenced by the levels of revenues and provisions. In other words, firms with higher provisions and revenues on average were those with higher disclosure of contingencies. Nevertheless, contrary to expectations, the governance level had a negative influence on the informativeness of the firms.

The main finding is that despite the increasing value of contingencies related to non-cumulative PIS and COFINS after the change in the calculation criterion, as shown by the official statistics, the firms were not concerned with disclosing that information in notes. In relation to the size of the companies studied, the general tax contingencies reported were relatively small.

Based on the data analyzed, it is not possible to state precisely whether the firms that did not disclose tax contingencies in general and those related to non-cumulative PIS and COFINS in particular in the period studied had such contingencies. Despite the zero disclosure rate in some sectors, such as pulp and paper, mining and transportation, it is highly likely that these firms have some contingencies related to PIS and COFINS, due to their characteristics.

The main limitation of this study is related to the inability to identify the companies having contingencies related to non-cumulative PIS and COFINS. We therefore recommend further research with identification with questionnaires.

\section{References}

Bruseke, Franz J. (2007). Risco e Contingência. Revista Brasileira de Ciências Sociais, 22(63).

Calijuri, Mônica, S. S. (2009). Avaliação da Gestão Tributária a partir de uma perspectiva multidisciplinar. Doctoral dissertation in accounting, Universidade de São Paulo.

Canado, Vanessa, R. (2011). COFINS - aspectos teóricos e práticos. Ed. Saraiva. São Paulo.

Carraza, R. A. (2002). ICMS. $8^{\circ}$ ed. p. 270, Malheiros, São Paulo.

Chuk, Elizabeth. (2013). Economic Consequences of Mandated Accounting Disclosures: Evidence from Pension Accounting Standards. The Accounting Review, 88(2), 395-427. 
http://dx.doi.org/10.2308/accr-50320

Cohen, Daniel, Darrough, Masako N., Huang, Rong, \& Zach Tzachi: (2011). Warranty Reserve: Contingent Liability, Information Signal, or Earnings Management Tool? The Accounting Review, 86(2), 569-604. http://dx.doi.org/10.2308/accr.00000021

Cysne, Rubens P., Issler, João V., Lima, Luiz R. R. O., \& Hostalacio, Hilton. (2006). Impacto do PIS e da COFINS na inflação: Uma abordagem econométrica usando o teste de janela variável. Economia Aplicada, 13(2), 185-201.

Desai, Mihir A., \& Dharmapala, Dhammika. (2007). Taxation and Corporate Governance: An Economic Approach. http://dx.doi.org/10.1007/978-3-540-77276-7_3

Fernandes, Fernando A. D., Teixeira, Arilton, Baptista, \& Ézio C.S. (2010). COFINS: Um estudo empírico dos efeitos da alteração de incidência sobre o lucro de empresas com ações negociadas na Bovespa e seu impacto na arrecadação tributária federal. Revista Brasileira de Gestão de Negócios, 12(35), 171-190.

Graham, John R. Raedy, Jana S, \& Shackelford, Douglas A. (2011). Research in accounting for income tax. (2011). Journal of Accounting and Economics, 53, 412-434. http://dx.doi.org/10.1016/j.jacceco.2011.11.006

Haddad, Roberto. (2004) Government Continues Reform of System of Social Taxes. International Tax Review, 15, 28-32.

Hanlon, Michele, \& Heitzman, Shane (2010). A review of tax research. 2010. Journal of Accounting and Economics, 50, 127-178. http://dx.doi.org/10.1016/j.jacceco.2010.09.002

Hermalin, Benjamin, E., \& Weibach, Michael, S. (2012) Information Disclosure and Corporate Governance. The Journal of Finance, 78(1). http://dx.doi.org/10.1111/j.1540-6261.2011.01710.x

Junqueira, Emanuel, R.: (2010). Perfil do sistema de controle gerencial sob a perspectiva da teoria da contingência. 2010. Doctoral dissertation in accounting, Universidade de São Paulo, São Paulo.

Kelsen, Hans. (2011). Teoria pura do direito. 8th ed. São Paulo.

Lima, Gerlando, A. S. F. (2009); Nível de Evidenciação x Custo da Dívida das Empresas Brasileiras. Revista Contabilidade \& Finanças, 20(49).

Lima, Emanoel, \& Pereira, Carlos (2012). Índice de disclosure das instituições filantrópicas de ensino superior no Brasil. Revista Portuguesa e Brasileira de Gestão, 11(1).

Macagnan, Clea B. (2009) Evidenciação Voluntária: Fatores Explicativos da Extensão da Informação Sobre Recursos Intangíveis. Revista Contabilidade \& Finanças, 20(50).

Madeira, Patrícia, H. B G. (2009) Não-cumulatividade do PIS e da COFINS. 2009. Master's dissertation in law, Faculdade de Direito da Universidade de São Paulo, São Paulo.

Mapurunga, Patrícia V. R., Ponte, Vera, M. R., Coelho, Antônio, C. D., \& Menezes, Anelise, F. (2011). Determinantes do nível de disclosure de instrumentos financeiros derivativos em firmas brasileiras. Revista Contabilidade \& Finanças, 22(57).

Moreiro, Rafael, L., Colauto, Romualdo, D., \& Amaral, Hudson, F. (2010). Conservadorismo condicional: estudo a partir de variáveis econômicas. Revista Contabilidade \& Finanças, 
21(54), São Paulo.

Oliveira, Fábio, R. (2011). PIS/Pasep e COFINS: O desalinhamento entre os conceitos contábil e fiscal de insumos e seu efeito sobre o resultado contábil das empresas brasileiras. 2011. Master's dissertation in accounting, Fundação Escola de Comércio Álvares Penteado, São Paulo.

Pimenta, Roberto A. (1972). A política tributária (IPI/ICM) e o desenvolvimento industrial. 1972. Revista de Administração de Empresas, 12, 51-61.

Ponte, Vera M. R., \& Oliveira, Marcelle C. (2004). A Prática da evidenciação de informações avançadas e não obrigatórias nas demonstrações contábeis das empresas brasileiras. Revista Contabilidade \& Finanças, 15(36), São Paulo.

Reagle, Derrick. (2006) Back on the balance sheet: The tax effects of contingent claims in commercial banking..Review of Financial Economics, 15, 19-27. http://dx.doi.org/10.1016/j.rfe.2005.01.002

Sayeg, Roberto N. (2003). Sonegação tributária e complexidade. RAE - eletrônica, 2(1).

Schadewitz, Hannu J., \& Blevins, Dallas R. (1998). Major determinants of interim disclosures in an emerging market. American Business Review, 16, 41, 15.

Schiff, Jonathan, Schiff, Allen, \& Rozen, Hannah (2012). Accounting for Contingencies: Disclosure of Future Business Risks. Management Accounting Quarterly, 13(3).

Xavier, Raquel M. M. (2011). Não cumulatividade do PIS e da COFINS: uma visão pragmática. Quartier Latin, São Paulo.

\section{Copyright Disclaimer}

Copyright for this article is retained by the author(s), with first publication rights granted to the journal.

This is an open-access article distributed under the terms and conditions of the Creative Commons Attribution license (http://creativecommons.org/licenses/by/3.0/). 